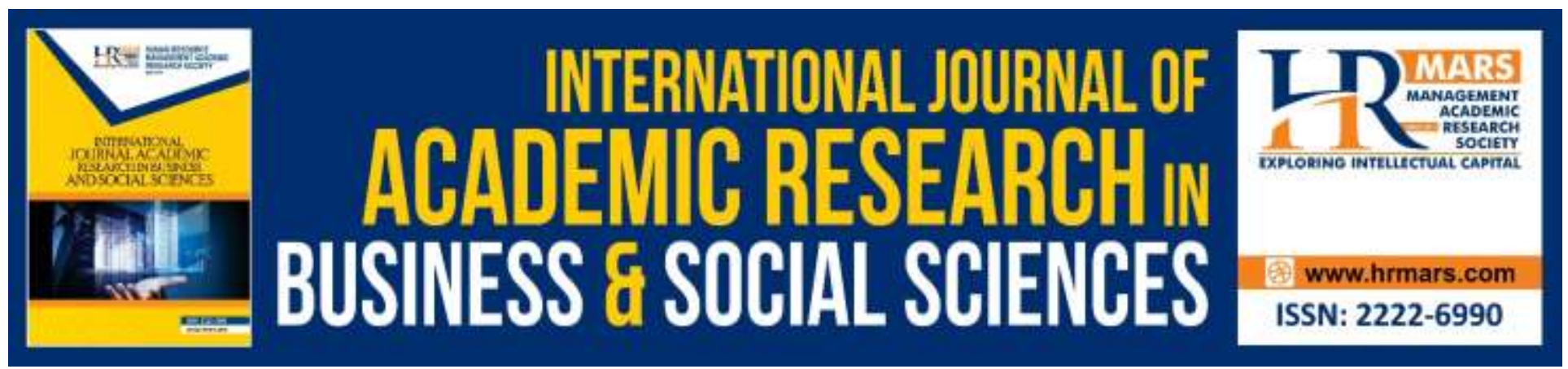

\title{
Sukuk Default: Could Corporate Governance \& Sustainability be the Defenders?
}

Awais Ur Rehman, Muhammad Abdullah bin Zaidel, Mohamad bin Jais, Arslan Haneef Malik

To Link this Article: http://dx.doi.org/10.6007/IJARBSS/v10-i5/7226

DOI:10.6007/IJARBSS/v10-i5/7226

Received: 08 March 2020, Revised: 23 April 2020, Accepted: 28 April 2020

Published Online: 21 May 2020

In-Text Citation: (Rehman et al., 2020)

To Cite this Article: Rehman, A. U., Zaidel, M. A. bin, Jais, M. bin, \& Malik, A. H. (2020). Sukuk Default: Could Corporate Governance \& Sustainability be the Defenders? International Journal of Academic Research in Business and Social Sciences, 10(5), 533-545.

Copyright: (c) 2020 The Author(s)

Published by Human Resource Management Academic Research Society (www.hrmars.com)

This article is published under the Creative Commons Attribution (CC BY 4.0) license. Anyone may reproduce, distribute, translate and create derivative works of this article (for both commercial and non-commercial purposes), subject to full attribution to the original publication and authors. The full terms of this license may be seen at: $\underline{\text { http://creativecommons.org/licences/by/4.0/legalcode }}$

Vol. 10, No. 5, 2020, Pg. 533 - 545

http://hrmars.com/index.php/pages/detail/IJARBSS

JOURNAL HOMEPAGE

Full Terms \& Conditions of access and use can be found at http://hrmars.com/index.php/pages/detail/publication-ethics 


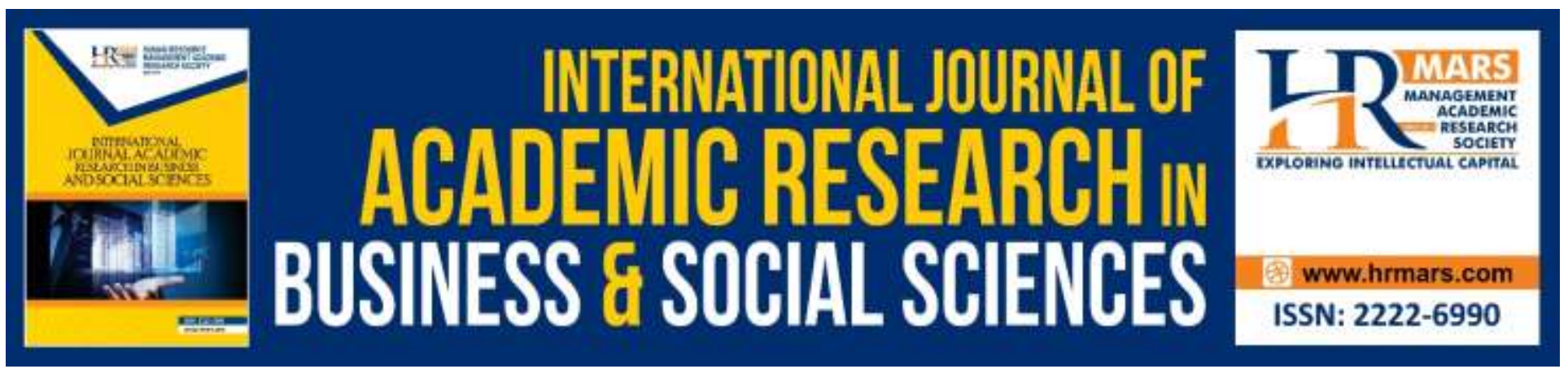

\title{
Sukuk Default: Could Corporate Governance \& Sustainability be the Defenders?
}

\author{
Awais Ur Rehman, Muhammad Abdullah bin Zaidel, Mohamad bin \\ Jais, Arslan Haneef Malik
}

Faculty of Economics \& Business, Universitl Malaysia Sarawak

\begin{abstract}
Malaysian sukuk. It grew larger due to blind market information about defaults, summing up the loss of USD 2.243 billion. Malaysian sukuk market still survived mainly due to petro-dollars and no competition pressure. By 2010, IMF and World Bank were unanimous to say that Malaysia had won the rightly envisioned status of global investment hub. More than $25 \%$ of sukuk assets, placed with her and $84 \%$ of short term sukuk are in MYR, certainly contributive to her GDP. By 2015 the sukuk market has entered into consolidation phase, with lesser issuances, stark down petroleum prices, sluggish post-crisis economy, down rated MYR, inflation and much higher competitive pressure. Saudi Arabia got IMF support for sukuk and Bahrain doubled its market share in a single year. This time the market forces would not relax Malaysia. Getting lesson from 2009, before the contagion ignites it is the time to check our safety measures against the default. Basing upon the logics drawn from extensive past literature this concept paper sorts the Corporate Governance (CG) and Sustainability (CS) for defensive mechanism against the defaults. Their inter-relation and relation with default risk have been discussed to reach over a conceptualized framework. It was observed that the CG-risk models are alone insufficient to make a plausible conclusion. CS has straightforward defensive role against defaults. But CG is clear to control CS. To say that CG-risk relation is better performed via CS performance. The discussion has been concluded in the managerial implications and directions for future research in the related fields.
\end{abstract}

\section{Introduction}

IMF has reported that Islamic finance has emerged as a reality in the daylight by showing it mettle and resilience against the recent financial crisis. Although its market share is just a niche so far, but its rapid growth has rendered it a significant penetration in the global market and especially in the Asia. The report goes on to state that Islamic finance and maintain its gleam and glosses by making the sukuk markets more efficient and resilient. The sukuks are important for Islamic fiancé since other Islamic financial institutions must depend on it for their liquidity and profitability. Therefore, it counts for a 95\% portion of global Islamic financial assets if sukuk assets are merged with Islamic banking assets. Secondly, it has a potential to grow more rapidly owing to its viability and outreach across the political borders (IMF, 2015; Ramadan, 2013; Suriani, Majid, \& Nazaruddin, 2018). Asia Bond Monitor of Asian Development Bank tells its average growth rate is $27.8 \%$, (Mohammed, 2015).. 
But that is only one side of the story. All is not perfect and promising in the sukuk markets. The jerks and jolts are there in its way. IIFM annual Sukuk report of 2015 says that the sukuk growth by 2012 and 2013 had been at its trajectory and by 2013 it got it high peaks with record issuances. Report terms that the sukuk has entered the "consolidation phase", where a range of external factors have started pressing the sukuk market negatively (IIFM, 2016, p. 3).

Only in Malaysia there was a series of defaults between 2000-2013 numbering 26 default cases. The highest defaults occurred in 2009. It was such a worse year in the history of capital markets of Islamic finance that researchers have coined it as the year of sukuk defaults (Shahida, Hafizuddin Syah, Daud, \& Hafizi, 2014; Kamarudin, Kamaluddin, Manan, \& Ghani, 2014). Researchers have also noted that these defaults have given a down swing in the sukuk market by impacting its issuances negatively (Majid, Shahimi, \& Abdullah, 2010).

Khinfer (2010) narrates that during his data collection on sukuk default, not only he from the academic circle, but also the personnel in the law firms and the credit rating agencies were mainly ignorant of the number of cases of sukuk defaults, since a few cases only were in the lime light. And lamenting it was when the researcher dug up with 21 defaults only in the short span of 20 months, means at least one default per month. 15 sukuk issuers were wrecked only in 2009 and the 6 cases flooded in coming 11 months. Lamenting was the want of knowledge in popular circles, and even more lamenting was the situation that true picture had been revealed by no ombudsman or regulator. Would the industry have not "turned blind" in alarming the stakeholders after the first default, the situation might have been different to not shake the industry like the economic jerks it received (Khnifer, 2010). For the defaults by 2012, Sukuk industry had paid the price of this negligence, in shape of a loss of USD 2.243 billion only in Malaysia (Kamarudin, Kamaluddin, Manan, \& Ghani, 2014). Once the defaults have occurred it can easily spread to the market. The default in the payment caused by one party can lead to the potential receiver to default as well for its obligations. Therefore, it become contagious. It becomes necessary to be prepared and discussing the mitigating tools aforehand. It can give an updated and timely picture of defaults and it can give an important input for decision making that what tools can be relied to what extent for credit risk management (Khalid, 2007; Saad, Haniff, \& Ali, 2016).

As discussed in preceding lines, sukuk has an eminent place in the financial market, yet owing to a relatively new phenomenon, studies upon it are limited. Taking the default measures as a focused issue and checking the impact of corporate governance and sustainability is vacant in the literature at all. Hence this research aims to bring forward the conceptualization of the role of Corporate Governance (CG) and Corporate Social Sustainability (CS) in defending against the evil of default in the scenario of sukuk issuance.

The next sections aim to highlight the role of CG and the CS in aforesaid directions. Then the discussion will be able to boil down to certain conceptualized scenario for forecasting the sukuk defaults. The significance of CG and CS are discussed in the upcoming sections. This discussion in the proceeding section is boiled down to conceptualize their standpoints in forecasting the sukuk defaults.

\section{Role of Corporate Governance in Default Risk}

CG is the set of internal rules, codified or precedential, to manage the functioning of a firm by operationalizing the inter-relations and hierarchy of personnel and the directors. CG has been praised by the past researches for its significant impact to efficiency, cost of equity and the firms' values. But 
establishing the empirical links between the CG and defaults had been an under-researched area (Bhagat \& Black, 2002; Bhagat, Bolton, \& Romano, 2008; Gompers, Ishii, \& Metrick, 2003; Chen, Chen, \& Wei, 2011; Akdogu \& Alp, 2016; Ijeoma \& Ezejiofor, 2013). Hence the overall arch building from the concerned literature is not concrete and needs a bit more bricks and mortals, yet it can be augmented plausibly that CG structures are important for sukuk credibility (Elhaj, Muhamed, Ramli, \& Zakaria, 2016).

Gompers, Ishii, \& Metrick (2003) divided the stocks into two portfolios the Democrats with high CG level and Dictators with lesser levels of CG. It was noted that the stock returns on the Dictator stocks were greater. It is plausible to imagine that the stocks with lower CG implementations were at higher level of risk and therefore paying more on the risk premium. It was also noted that in the absence of CG implementations, agency issues can get bigger and the cash usage for the CEO renumerations (Core, Guay, \& Rusticus, 2006). These two factors can increase the default risk on aggregate.

The cash holdings in the corporates can be another viewpoint to probe the relation of CG to default risk. The free and idle cash can impede the firms' profitability with a double edge sword. It can decrease the investment size and renders a heaven to CEO to benefit from the cash other than the renumerations. It was noted by some studies that the CG, measured by antitakeover mechanisms, can decrease the unwise cash holdings (Yun, 2008). While if the CG is measured on bigger range of its constituents, it was noted that the CG is increasing the risk of holding more cash (Harforda, Mansib, \& Maxwell, 2008).

Specifically focusing on default risk, it was exhibited by a study that the board independence an institutional ownership is inversely related to the risk. The Risk was measured by Merton model. Once the risk was measured by the proxy of CD spreads. The relationship of board independence became insignificant (Switzer, Wang, \& Tu, 2016). On the other hand, CD spread was decreased by the antitakeover mechanism of CG (Akdogu \& Alp, 2016). Another study took a long list of CG variables at independent side and the default risk was the dependent variable. It was noted that only some variables were showing the significant results. Board composition with smaller size, gender diversity and independent directors decreased the default risk while the institutional ownership had a positive effect on default closeness (Cao, Leng, Feroz, \& Davalos, 2015). It was further noted that the CG impact on default risk is insignificant once the endogeneity issues are controlled by GMM (Schultz, Tan, \& Walsh, 2015).

Overall the directors can be unable to bring down the level of risk in an organization. Every organization has a risk culture and an appetite for taking the risk and return combinations. This risk culture is stubborn and can not be reversed especially once proven effective for profits. All the shareholders are not able to understand complex risk calculations they can merely assume the returns added to it. They support the directors good in taking risk according to their own preferences. CG measures are also aimed to protect shareholders mostly. Risk is managed in accordance with the competitive market culture not by the boards (Fahlenbrach \& Stulz, 2011; Iqbal, Strobl, \& Vähämaa, 2015; Mehran, Morrison, \& Shapiro, 2011). The board is compelled to take risk even after the threshold level of credit stress has been crossed (Fich \& Slezak, 2008). While Ben Zeineb \& Mensi (2018) has noted that the risk taking is further increased by the free-rider issues in the board members. On other hand "dark side expertise" of the board can be another medium to increase the risks. The directors are paid for their skills not to manage the risk instead to rectify the risk levels the organization wants to take. Their renumerations are paid by the corporates so they have to follow them (Mehran, Morrison, \& Shapiro, 2011, p. 10). The hypothesis of dark side expertise was further 
reasserted by the empirical evidences of related studies (Minton, Taillard, \& Williamson, 2014; Iqbal, Strobl, \& Vähämaa, 2015).

Overall the relationship of CG to default risk is biangular. The CG can increase firm value that results in the risk decrease (Chen, Chen, \& Wei, 2011; Gompers, Ishii, \& Metrick, 2003). While From the angle of shareholders' empowerment it can cause an increase in the risk (Vateva, 2014). The impact of CG upon default risk is conceptualized to have is positive, with respect to shareholders or owners right and cash. While this relation is expected to be negative via the firm value and disclosures. Is it possibly to camping the two opposite poles at the same time? These two probable relations as envisioned in the above discussion are mutually inconsistent. Having said it clearly means the model specification is not satisfactory up to the current body of knowledge. It clearly calls for two steps. Firstly, the selection of GC variables must be cautious one under the nature of the study and context. Secondly, the modeling should be better done in path analysis by the inclusion of a new and related variable. Can the variable of CS be expected as significant variable here for the discussion of GC and default risk? This study shows in next sections that the inclusion of the CS variable can be a good choice.

\section{Role of Corporate Social Sustainability in Default Risk}

Sidney Homer an affiliate to the Salmon Brothers, is considered as the father of research in financial bonds. He narrates that the history of bonds dates to 1550, but the stakeholder pressure being faced by the issuers is the highest one in whole course of the history. Stakeholder management by engaging in social projects gives a positive fame to the market players and an acceptance among the public at large. It allows a low-cost capital to the issuers in primary market and a liquidity in the secondary market as well. Market place is hence not for "deviants" in continuing their business without having a well place, not merely theoretical but operationally effective, for the standards "accepted and indeed dictated by the community as a whole" (Homer, 1975, pp. 388-389). These positive reasons have encouraged the boards and the managers to welcome the CS activities in their daily working. The researchers have also responded well on the issue but still the link between the default risk and CS performance is not much researched. For instance meta-analysis covered on the relationship between the CS and risk are vacant to cover the default risk (Orlitzky \& Benjamin, 2001; Wang, Dou, \& Jia, 2015) 


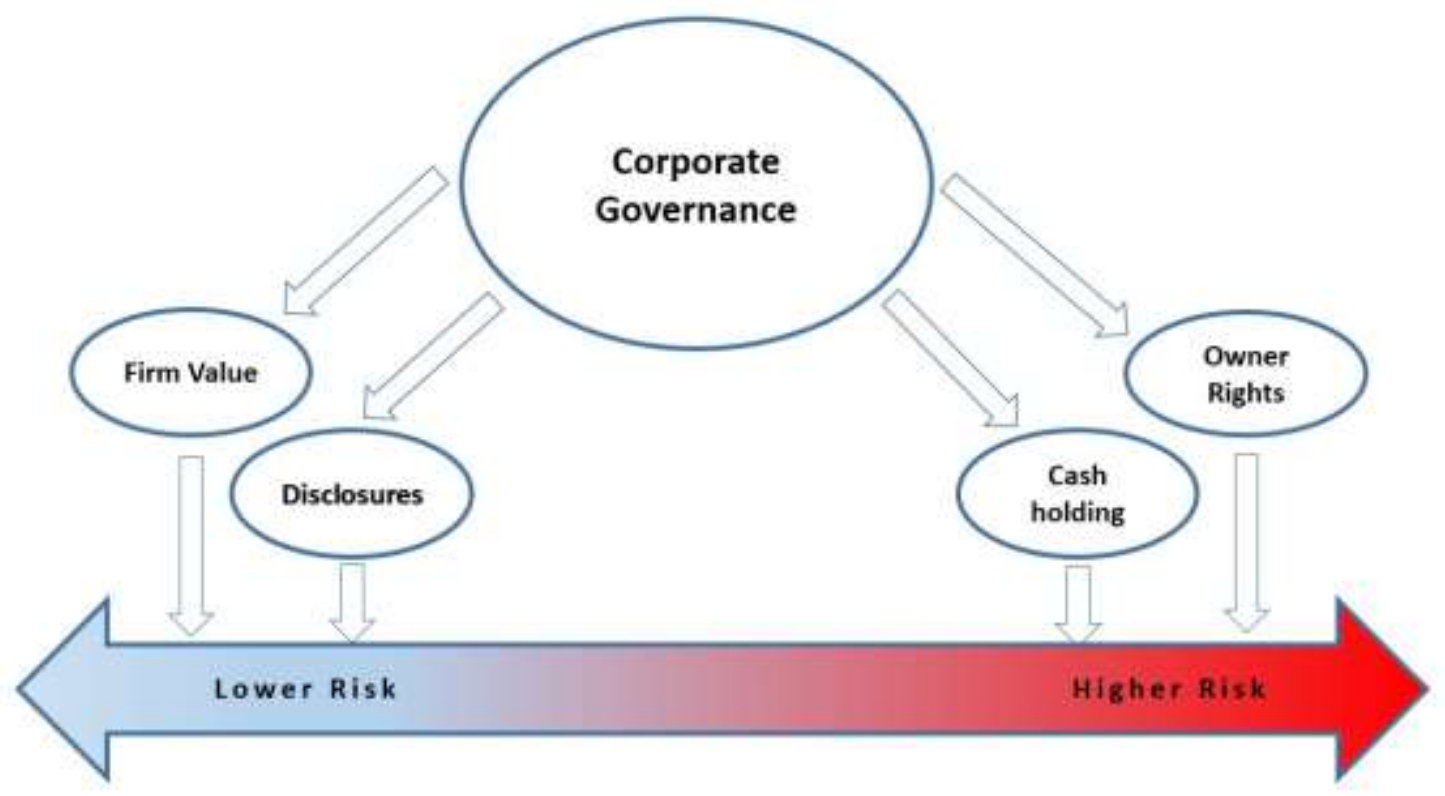

Figure 1: Biangular impact of CG upon Risk

The CS performance of the firms can bring loyalty among their customers. The purchases decisions of these loyal customers are less effected with the negative shocks. This lower elasticity of demand can bring a stability in the earnings and decreases the risk. It was also noted that these firms have lesser administrative expenses and hence a stable operating leverage (Albuquerque, Durnev, \& Koskinen, 2015). CS activities also yields a better relationship with the regulating and supervisory bodies. The CS concerns makes the firms ethical and efficient in compliance even more than the minimum legal requirement. That way the firms can enjoy less legal risk and lesser penalties imposed on them (Wang, Lin, Kao, \& Fung, 2016; McGuire, Sundgren, \& Schneeweis, 1988). CS performance makes the firms better in their competitive behavior to the fellow market players (Spicer, 1978). It can make them efficient in their supply chain management and credit purchases.

The CS projects can be of varied nature. Generally, they rest upon three bigger pillars, viz; economic, environmental and social CS. All of these have their abilities to lessen the risk level of the firms. Economic CS being the bases of all other projects has its central importance. It was noted that the economically sustained business can bring the social and environmental sustainability in its operations (Carroll, 1991; Nasir, Halim, Sallem, Jasni, \& Aziz, 2015). It was noted that this phenomenon holds true for the macro level too. The countries better in their economic sustainability were noted to have better performance in other domains of CS. While studies have also shown that economic CS can bring decrease in the firm risk significantly (Torugsa, O'Donohue, \& Hecker, 2013; Weber, Fenche \& Scholz, 2008)

Environmental performance is an important constituent of CS performance. The World Bank has recommended that the environmental performance must be made a part of the credit evaluation of the borrowers. Hence, the borrowers with more environmental-friendly strategies would have to pay a lesser risk premium and can enjoy low cost debt (Weber, Fenche, \& Scholz, 2008). It was also noted 
INTERNATIONAL JOURNAL OF ACADEMIC RESEARCH IN BUSINESS AND SOCIAL SCIENCES Vol. 10, No. 5, May, 2020, E-ISSN: 2222-6990 @ 2020 HRMARS

by empirical findings that the environmental CS performance can reduce the firm risk (Benlemlih, Shaukat, Qiu, \& Trojanowski 2018; Suto \& Takehara, 2018).

Social dimension of CS makes the firms responsible in their employee retention \& turnover by paying a proper attention to benefits provided to employees and occupational health and safety. Therefore, these firms are observed to have lesser HR issues (Soloman \& Hansen, 1985). These HR efficient strategies of the firms make them able to manage their risk levels more easily. It was found that the social CS performance impacts the firm risk negatively (Benlemlih, Shaukat, Qiu, \& Trojanowski 2018; Suto \& Takehara, 2018).

Foremost and directly taking on risk Wang, Dou, \& Jia (2015) carried out a meta-analysis from the past literature to elucidate the relation of CS performance to the risk profile of relevant company. The analysis was arched upon the instrumental theory of stakeholders. Theory relates the stakeholder management activities to the final goals a business needs to achieve as the part of its strategy. It tells that the business if takes care of the stakeholders, the pays-off are back to the shareholders via making the business to achieve its goals more efficiently. Instrumental relation between the CS and risk was the focus of the study in terms of the direction of the relation. This direction of cause and impact relation was assumed reciprocal. By the data analysis of large across the country analysis, it was noted that impact was not the bi-directional.

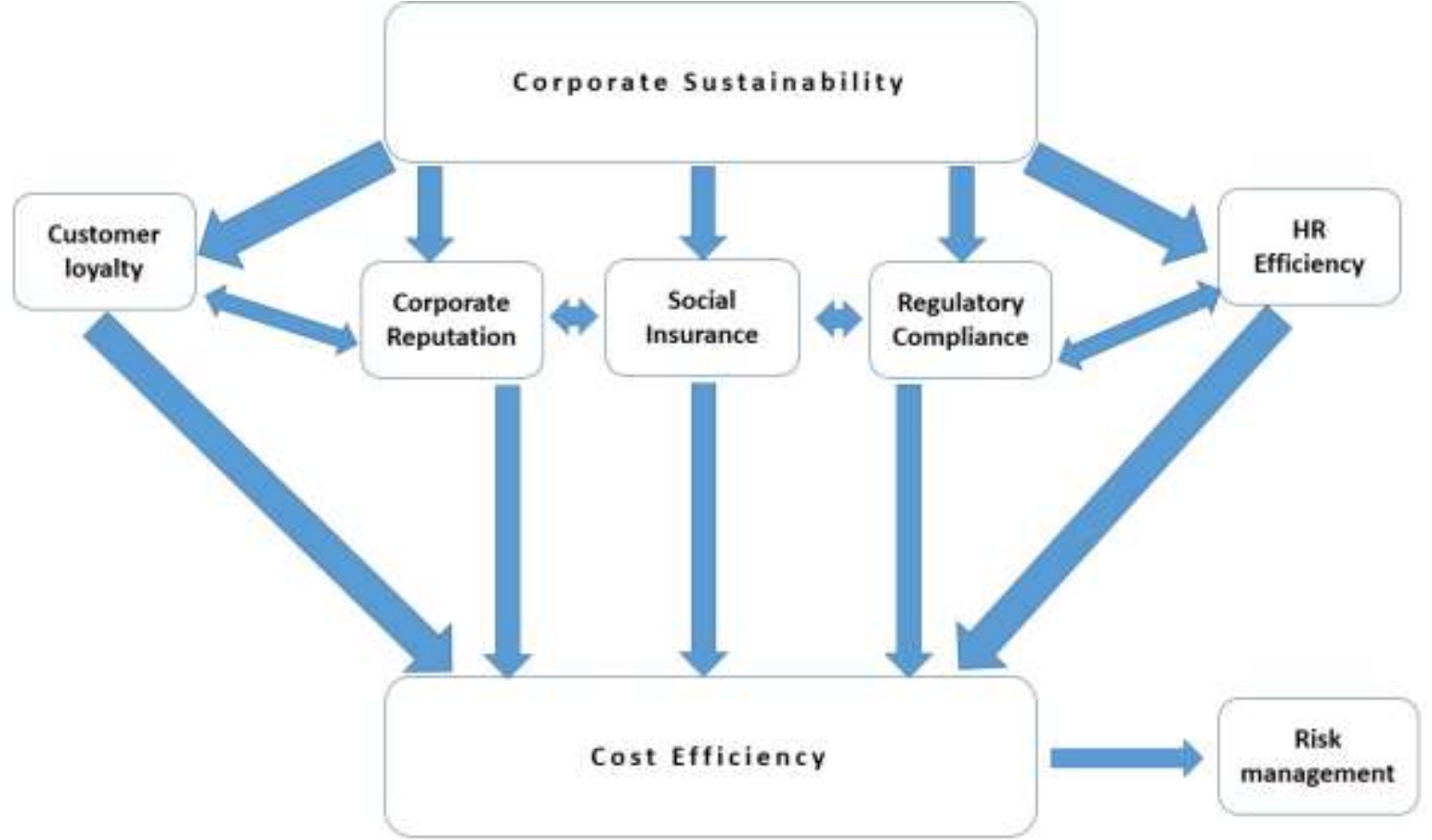

Figure 2: Impact of CS upon risk via multi factors

\section{Special Status of Sukuk}

The Islamic financial products and investments are thought to be resilient ostensibly. They are considered safe to take more risk because they are safe for it because they are built upon profit and loss sharing (PLS) theory. The Islamic financial industry is built upon the principle of no usury or interest. The alternative mechanism was missioned on two-tier PLS. That the investments and profits both on the asset and liability sides, will be welcomed on PLS, while, the managing institute will keep its margin (Usmani, 2009; Abdul-Rahman, Latif, Muda, \& Abdullah, 2014). Based on this model it is 
widely assumed that Islamic financial industry is resilient against risk taking, since it shares its risk with investors (El Haloui \& Aboulaich, 2019). The foundations of Islamic finance make the system at macro level more responsible for economic sustainability and at the micro level resilient and agnostic to the credit stress (EI Haloui \& Aboulaich, 2019). This risk hypothesis gained its fame in the postcrisis era once most of Islamic banks showed their resilience against the fall in crisis. This study arguments that this assumption is unrealistic. Firstly, merely compliant to PLS mechanism is not enough, as witnessed by the series of sukuk defaults and losses. Secondly, this theory is not applied in many Islamic financial products. The major assets of Islamic financial institutes are managed on non-PLS mechanism. That makes the Islamic financial products as susceptible to defaults as the conventional counterparts.

Specifically, in the case of sukuks, it was exhibited based on empirical data, that the sukuks based on PLS theory are launched to reduce the information asymmetry risk. The issuers once confronted with uncertainties due to want of information, they choose PLS sukuk to share their risk with investors (ElKhatib \& Patel, 2009). Financial indices like Dow Jones, S\&P, FTSE, MSCl, etc. have witnessed that the investors' confidence is increasing in Islamic investments after the crisis (Alqahtani, 2009). While, specifically talking about sukuks, the investors' confidence is highly in the favour of the industry. The sukuks are 4 to 6 times oversubscribed (KIB, 2019; Ace Group, 2016; BNM, 2015). Sukuk issuances in this scenario provides the issuers a dependable trail of financing. Assuming that they are naturally resilient against the risk and are oversubscribed, can induce the issuers to think that they are too big to fall. It can induce the issuers to take more risk (Colan, 2017). Too big to fall is a managerial assumption as a moral hazard that encourages the big firms to take risk on the intuition that even the biggest risk are worth nothing to worry, owing to their big size (Acharya \& Thakor, 2016). Another phenomenon that the Islamic financial institutes are new entrants of the market they have to play aggressively to compete their older counterparts, triggers up their risk taking as well (Ben Zeineb \& Mensi, 2018). It has been reported that the sukuk issuances in a market increases competitive pressure that trends other market players to increase their overall risk taking (Smaoui \& Ghouma, 2020). In this wake the CG board members may allow them to take risk. These issues give the height in risk management process of sukuk and makes it akin to have a better CG measures (Elhaj, Muhamed, Ramli, \& Zakaria, 2016).

\section{Conclusion and the way Forward}

Sukuk is witnessing a promising growth. But to maintain its growth trajectory and veracity of investors confidence the need of the hours is to make it resilient against defaults. The past defaults have shaken the market with severe losses the aftermaths of the crisis are not over yet. Therefore, their closeness to defaults and the tools to analyze resilience must be updated timely. Getting lesson from 2009, before the contagion ignites it is the time to check our safety measures against the default. Basing upon the logics drawn from extensive past literature the CG and CS are conceptualized to make the defensive mechanism against the defaults. The models with taking only CG as variable to tackle with risk ends up in a mutually inconsistent and exclusive biangular role of CG. This inconsistency is also the results of multifaceted nature of CG. Hence firstly the dimensions of CG be carefully selected. Secondly, the CS has quite appreciable mediating role while the CS is going to be controlled by CG and both are promising to manage default risk. Hence the impact of CG is better formulated through the CS. It is pertinent to note that both CG and CS must be taken together to have a holistic tool set against default risk. 
Aras \& Crowther (2008) argued that the CG and CS can be brought together on their theoretical under pining. They define the CG “... creating a balance between the economic and social goals of a company including such aspects as the efficient use of resources, accountability in the use of its power, and the behavior of the corporation in its social environment (Aras \& Crowther, 2008, p. 441)". The CS mandates the corporates to achieve their goals in economic, social and environmental aspects of CS, while the CG operationalizes these goals. Both are aligned in their objectives and complement each other in creating the economic value for the firm and decreasing the risk. This argument is based upon the stakeholder theory. While based on the agency theory it can be augmented that current scandalous corporate environment has highlighted the agency issues. The managerial authorities have taken the managers away from the ethical standards of stewardship. The CS projects, owing to weaker assurance and auditing, can be a safe haven for the managers. It can beget more scandals and agency issues. While if their powers are construed too narrowly, the CS performance cannot be made. That can be a risk on the basis of social sustainability. Hence, the authority and supervision are both necessary at the parallel. It paves the way for CG to control and manage CS activities in the favor of corporates (Heath \& Norman, 2004). The relationship of CG to CS is also tested empirically in the past literature (Kolk J., 2008).

The nature of the study was qualitative owing to the concept paper a clear limitation. The findings are off course jeopardized to this limitation. Hence an empirical study in response to this research has already been started by the authors. Another point to ponder that CG must be incorporated carefully with respect to its dimensions and their role to risk. This point can be the object of an independent research that what dimension related to the analysis of what kind of risk. This analysis can be business specific too. For corporate sector the literature is abundant as compared to SME. The research can be carried for them too. Behavioral aspects of the board can also be incorporated. Moreover, CG and CS, their relations to risk were discussed through different ways and variables, e.g. cost affectivity, cash holding, etc. The supporting literature was not mostly a mediation analysis. Hence the empirical researches are crucial here to elucidate that what variable is related econometrically and what not in order to conclude with a composite model.

\section{References}

Ace Group. (2016). Malaysia says $\$ 1.5$ billion sukuk oversubscribed. Capital Management.

Akdogu, E., \& Alp, A. (2016). Credit risk and governance: Evidence from credit default swap spreads. Finance Research Letters, 17(1), 211-217.

Alam, N., Hassan, M. K., \& Haque, M. A. (2013). Are Islamic bonds different from conventional bonds? International evidence from capital market tests. Borsa Istanbul Review, 13(1), 22-29.

Albuquerque, R. A., Durnev, A., \& Koskinen, Y. (2015). Corporate Social Responsibility and Firm Risk: Theory and Empirical Evidence. ECGI.

Aldamen, H., Duncan, K., \& Khan, S. (2012). Governance-default risk relationship and the demand for intermediated and non-intermediated debt. Australiasian Accounting, Business and Finance Journal, 6(1), 25-42.

Alqahtani, D. S. (2009). Global Islamic Index Providers: The Wrong Choice. The Journal of Investing, 79-81.

Aras, G., \& Crowther, D. (2008). Governance and sustainability. Management Decision, 46(3), 433 448. 
INTERNATIONAL JOURNAL OF ACADEMIC RESEARCH IN BUSINESS AND SOCIAL SCIENCES

Vol. 10, No. 5, May, 2020, E-ISSN: 2222-6990 @ 2020 HRMARS

Ben Zeineb, G., \& Mensi, S. (2018). Corporate governance, risk and efficiency: evidence from GCC Islamic banks. Managerial Finance, 44(5), 551-569.

Benlemlih, M., Shaukat, A., Qiu, Y., \& Trojanowski, G. (2018). Environmental and social disclosures and firm risk. Journal of Business Ethics, 152(3), 613-626.

Bhagat, Bolton, B., \& Romano, R. (2008). The Promise and Peril of Corporate Governance Indices. Columbia Law review, 108(8), 1803-1882.

Bhagat, S., \& Black, B. S. (2002). The Non-Correlation Between Board Independence and Long-Term Firm Performance. Journal of Corporation Law, 231-273.

BNM. (2015). Global Sukuk Report $1 Q$ 2015. Malaysia World's Islamic Finance Marketplace.

Cao, Z., Leng, F., Feroz, E. H., \& Davalos, S. V. (2015). Corporate governance and default risk of firms cited in the SEC's Accounting and Auditing Enforcement Releases. Review of Quantitative Finance and Accounting, 44(1), 113-138.

Carroll, A. (1991). The Pyramid of Corporate Social Responsibility: Toward the Moral Management of Organizational Stakeholders. Business Horizons, 34(4), 39-48.

Chen, H. (2008). The timescale effects of corporate governance measure on predicting financial distress. Review of Pacific Basin Financial Markets and Policies, 11(1), 35-46.

Chen, K. C., Chen, Z., \& Wei, K. C. (2011). Agency Costs of Free Cash Flow and the Effect of Shareholder Rights on the Implied Cost of Equity Capital . Journal of Financial and Quantitative Analysis, 46(1), 171-207.

Colan, A. (2017). Running Musharakah; Discussions \& Dialogues at Islamic Economic Forum. (K. Hasani, Interviewer)

Core, J., Guay, W., \& Rusticus, T. (2006). Does weak governance cause weak stock returns? An examination of firm operating performance and investors' expectations. Journal of Finance, 61(1), 655-687.

Daily, C. M., \& Dalton, D. R. (1994). Bankruptcy and Corporate Governance: The Impact of Board Composition and Structure. The Academy of Management Journal, 37(6), 1603-1617.

El Haloui, M., \& Aboulaich, R. (2019). Leveraged buyout booms and busts: can Islamic finance help prevent and mitigate such market distortions? Investment Management \& Financial Innovations, 16(1), 299-318.

Elhaj, M. A., Muhamed, N. A., Ramli, N. M., \& Zakaria, N. B. (2016). Ownership monitoring mechanism over sukuk credit rating. International Journal of Academic Research in Business and Social Sciences, 6(12), 2222-6990.

El-Khatib, H., \& Patel, Z. (2009). Risk Management. Risk Management: Islamic Economic and Islamic EthicoLegal Perspectives on the Current Financial Crisis (pp. 1-26). London, UK: Islamic Finance Project Harvard Law School Islamic Legal Studies Program, London School of Economic.

Fahlenbrach, R., \& Stulz, R. M. (2011). Bank CEO incentives and the credit crisis. Journal of financial economics, 99(1), 11-26.

Fich, E. M., \& Slezak, S. L. (2008). Can corporate governance save distressed firms from bankruptcy? An empirical analysis. Review of Quantitative Finance and Accounting, 30(2), 225-251.

Godlewski, C. J., Turk-Ariss, R., \& Weill, L. (2013). Sukuk vs. conventional bonds: A stock market perspective. Journal of Comparative Economics, 41(1), 745-761.

Gompers, P. A., Ishii, J. L., \& Metrick, A. (2003). Corporate Governance and Equity Prices. Quarterly Journal of Economics, 108(1), 107-155. doi:http://dx.doi.org/10.2139/s 
INTERNATIONAL JOURNAL OF ACADEMIC RESEARCH IN BUSINESS AND SOCIAL SCIENCES

Vol. 10, No. 5, May, 2020, E-ISSN: 2222-6990 @ 2020 HRMARS

Harforda, J., Mansib, S. A., \& Maxwell, W. F. (2008). Corporate governance and firm cash holdings in the US. Journal of Financial Economics, 87(3), 535-555.

Heath, J., \& Norman, W. (2004). Stakeholder Theory, Corporate Governance and Public Management: What can the History of State-Run Enterprises Teach us in the Post-Enron era? Journal of Business Ethics, 53(1), 247-265.

Homer, S. .. (1975). The Historical Evolution of Today's Bond Market. Explorations in Economic Research, 2(3), 378-389.

IIFM (2016). Sukuk Report A Comprehensive Study Of The Global Sukuk Market 5th Edition. Manama, Kingdom of Bahrain: IIFM.

Ijeoma, N., \& Ezejiofor, R. A. (2013). An Appraisal of Corporate Governance Issues in Enhancing Transparency and Accountability in Small and Medium Enterprises (SME). International Journal of Academic Research in Business and Social Sciences, 3(8), 162-176.

IMF. (2015). Islamic Finance and the role of IMF. International Montary Fund. Retrieved January 1, 2017, from http://www.imf.org/external/themes/islamicfinance/

Iqbal, J., Strobl, S., \& Vähämaa, S. (2015). Corporate governance and the systemic risk of financial institutions. Journal of Economics and Business, 82(1), 42-61.

Joriona, P., \& Zhangb, G. (2007). Good and bad credit contagion: Evidence from credit default swaps. Journal of Financial Economics, 84(3), 860-883.

Kamarudin, M. F., Kamaluddin, N., Manan, S. K., \& Ghani, G. M. (2014). Defaulters profile in Malaysia Sukuk market. Procedia - Social and Behavioral Sciences 145 ( ), 145(2014), 277 - 285.

Khalid, A. M. (2007). Bond Market Developments in Emerging Markets: Prospects and Challenges for Pakistan. SBP Research Bulletin, 3(1), 43-62.

Khnifer, M. (2010, Dec 18). Shocking 21 Defaulted Sukuk Cases In the Last 20 Months. Thomson Reuters Zawya, pp. 24-26.

Khnifer, M. (2010, August 31). When Sukuk Default - Asset Priority of Certificate-Holders Vis a Vis Creditors. Opalesque Islamic Finance Intelligence, p. 9.

KIB (2019). RM850.0 million Sukuk Murabahah Issuance by Prasarana Oversubscribed by 4 Times. Kenanga Investment Bank Berhad.

Kolk, J. (2008). Sustainability, accountability and corporate governance: Exploring multinationals' reporting practices. Business Strategy and the Environment, 17(1), 1-15.

Lee, T. S., \& Yeh, Y. H. (2004). Corporate governance and financial distress: evidence from Taiwan. Corporate Governance: An International Review, 12(1), 378-388.

Majid, H. A., Shahimi, S., \& Abdullah, M. H. (2010). Sukuk defaults and its implication: a case study of Malaysian capital market. Proceedings of the eighth International Conference on Islamic Economics and Finance. Doha: Center for Islamic Economics and Finance, Qatar Faculty of Islamic Studies, Qatar Foundation.

McGuire, J. B., Sundgren, A., \& Schneeweis, T. (1988). Corporate Social Responsibility and Firm Financial Performance. The Academy of Management Journal, 31(4), 854-872.

Mehran, H., Morrison, A. D., \& Shapiro, J. D. (2011). Corporate governance and banks: What have we learned from the financial crisis? New York: FRB of New York Staff Report.

Minton, B. A., Taillard, J. P., \& Williamson, R. (2014). Financial expertise of the board, risk taking, and performance: Evidence from bank holding companies. Journal of Financial and Quantitative Analysis, 49(2), 351-380. 
INTERNATIONAL JOURNAL OF ACADEMIC RESEARCH IN BUSINESS AND SOCIAL SCIENCES

Vol. 10, No. 5, May, 2020, E-ISSN: 2222-6990 @ 2020 HRMARS

Mohammed, N. (2015, January 16). Global Growth Trends in Sukuk. Retrieved January 2, 2017, from Islamic Finance: https://www.islamicfinance.com/2015/01/global-growth-trends-insukuk/\#_ftn2

Nasir, N. E., Halim, N. A., Sallem, N. R., Jasni, N. S., \& Aziz, N. F. (2015). Corporate Social Responsibility: An Overview from Malaysia. Journal of Applied Environmental and Biological Sciences, 4(10S), 82-87.

Orlitzky, M., \& Benjamin, J. D. (2001). Corporate social performance and firm risk: a meta-analytic review. BUSINESS \& SOCIETY, 40(4), 369-396.

Platt, H., \& Platt, M. (2012). Corporate board attributes and bankruptcy. Journal of Business Research, 65(1), 1139-1143.

Ramadan, Z. S. (2013). Jordanian criteria for Islamic banks selection. Evidence from the Jordanian banking sector. International Journal of Academic Research in Accounting, Finance and Management Sciences, 3(3), 139-145.

Saad, N. M., Haniff, M. N., \& Ali, N. (2016). The Role of Institutional Investors in Mitigating the Default Risks of Sukuk and Conventional Bonds. Procedia Economics and Finance, 35(1), 339 - 348.

Schultz, E. L., Tan, D. T., \& Walsh, K. D. (2015). Corporate governance and the probability of default. Accounting and Finance, 1-19.

Shahida, S., Hafizuddin Syah, B., Daud, M. B., \& Hafizi, A. (2014). Predicting Probability of Defaults: The Case of Malaysian Sukuk Market. Persidangan Kebangsaan Ekonomi Malaysia ke-9 (PERKEM ke-9), (pp. 357 - 365). Kuala Terengganu,Terengganu.

Smaoui, H., \& Ghouma, H. (2020). Sukuk market development and Islamic banks' capital ratios. Research in International Business and Finance, 57(1), 1-17.

Soloman, R., \& Hansen, K. (1985). It's good business. New York: Atheneum.

Spicer, B. H. (1978). Investors, corporate social performance, and information disclosure: An empirical study. Accounting Review, 53(1), 94-111.

Suriani, M., Majid, R. M., \& Nazaruddin, A. W. (2018). Macroeconomic Determinants of the Capital Market in Indonesia: A Comparative Analysis between Sukuk and Bonds Markets. Journal of Academic Research in Economics and Management Sciences, 7(2), 1-17.

Suto, M., \& Takehara, H. (2018). Corporate Social Responsibility and Corporate Finance in Japan. Springer.

Switzer, L. N., Wang, J., \& Tu, Q. (2016). Corporate Governance and Default Risk in Financial Firms over the Post Financial Crisis Period: International Evidence. Financial Institutions, Regulation \& Corporate Governance (FIRCG) (p. 2016). Melbourne : Melbourne Business School.

Torugsa, N. A., O'Donohue, W., \& Hecker, R. (2013). Proactive CSR: An empirical analysis of the role of its economic, social and environmental dimensions on the association between capabilities and performance. Journal of Business Ethics,, 115(2), 383-402.

van Wijnbergen, S., \& Zaheer, S. (2013). Sukuk Defaults: On Distress Resolution in Islamic Finance. The Netherlands: Tinbergen Institute.

Vateva, T. K. (2014). Corporate Governance and default Risk. Kent State University.

Wang, L.-H., Lin, C.-H., Kao, E. H., \& Fung, H.-G. (2016). Good deeds earn chits? Evidence from philanthropic family controlled firms. Review of Quantitative Finance and Accounting , 1-19.

Wang, Q., Dou, J., \& Jia, S. (2015). A Meta-Analytic Review of Corporate Social Responsibility and Corporate Financial Performance: The Moderating Effect of Contextual Factors. Business \& Society, 55(8), 1083-1121. 
INTERNATIONAL JOURNAL OF ACADEMIC RESEARCH IN BUSINESS AND SOCIAL SCIENCES

Vol. 10, No. 5, May, 2020, E-ISSN: 2222-6990 @ 2020 HRMARS

Weber, O., Fenche, I. M., \& Scholz, R. W. (2008). Empirical analysis of the integration of environmental risks into the credit risk management process of European banks. Business Strategy and the Environment, 17(1), 149-159.

Wigglesworth, R. (2009). Defaults will test limits of Islamic debt. Financial Times.

Yun, H. (2008). The Choice of Corporate Liquidity and Corporate Governance. The Review of Financial Studies, 22(4), 1447-1475. 